\title{
The Agrarian Class Structure and Industrial Workers
}

In the closing decades of the nineteenth century, capitalist development greatly speeded up the dissolution of traditional social structures. New divisions opened the way for conflicts within the agrarian population, and an industrial proletariat emerged. The two processes were linked in that Finland's industrialisation was based mainly on the exploitation of its forests.

\section{The Industrial and Agricultural Revolutions in Finland}

Stein Rokkan has argued that the considerable agrarian support the Social Democrats received in Finland resulted largely from the late start of emigration or, more specifically, from the rapid growth of the landless proletariat, which was a consequence of this late start. ${ }^{1}$ This point becomes clear in the light of more fundamental processes, namely the industrial and demographic revolutions, which in Finland, as elsewhere in Eastern Europe, were chronologically distinct. There, because the onset of the population growth preceded industrialisation and economic growth, a large 'surplus' agrarian population was created before industrialisation could effectively absorb it. ${ }^{2}$

This situation was peculiar to the peripheral areas in the capitalist transformation of Europe. In the West - that is, in the core areas of capitalist development - the demographic revolution was a concomitant and constituent part of the industrial revolution itself. And not only that: population growth was inseparably linked to the simultaneous modernisation of the whole economy, which included both an industrial and a related agricultural revolutions. ${ }^{3}$ Unlike Finland and the other Eastern regions, the countries of Western Europe industrialised at a fairly steady pace during the latter half of the nineteenth century and the beginning of the twentieth, deriving most of the required workforce from the growing landless population. In Sweden, for instance, industrial development (as well as emigration) absorbed the new agrar-

1 Rokkan 1981, pp. 69-70.

2 Berend and Ránki 1982, pp. 44-8.

3 Ibid., pp. 44-5.

(C) KONINKLIJKE BRILL NV, LEIDEN, 2019 | DOI:10.1163/9789004386174_004

This is an open access chapter distributed under the terms of the CC BY-NC-ND $4_{R} 0$ license lapuro $_{\text {- }} 9789004386174$ 
ian proletariat, which was then becoming established as the population in the commercialising agricultural sector increased. The agricultural and industrial revolutions thus managed to keep pace with each other, as they did in Western Europe as a whole: the emerging rural proletariat was gradually dissipated. Sweden even experienced shortages of agricultural workers in the early years of the twentieth century. ${ }^{4}$ In the West, in short, the problems of population increase were never as acute as they were in the East.

Eastern Europe, with its growing population, remained predominantly agricultural for a longer time. Instead of a 'balanced' process of industrialisation aided by an agricultural revolution, agricultural transformation preceded industrialisation. This development resulted from the almost unlimited market in the West for Eastern European cereals, meat, fruit, and other foodstuffs. The demand caused Eastern European agriculture to grow dependent on developed Western European capitalism and brought about several agrarian reforms that were aimed at transforming manorial estates into large capitalist farms. When the peasants were freed from feudal ties to their landlords, a new class of agricultural wage workers emerged, particularly in Hungary and Romania. These reforms took place near the middle of the century and immediately thereafterwell before the industrial take-off, and therefore well before the increase in population could be absorbed by industry. As a result, the industrial revolution was not directly associated with the capitalist transformation in agriculture but was delayed until the end of the nineteenth and the beginning of the twentieth centuries. With one-sided agrarian advance constituting the dynamic and decisive process, and with no strong links to an overall process of economic development 'carrying everything with it', development in Eastern Europe was thus mainly dependent on external factors. ${ }^{5}$

In Finland, however, the interaction of the industrial and agricultural revolutions was different than in the rest of Eastern Europe. Because Finland's capitalist transformation was based primarily on the rise of the forest industry, changes occurred immediately in the countryside. There new industrial centres grew up and there, unlike elsewhere, peasants owned the bulk of the best forest lands. The effects of industrialisation were therefore exceptionally direct and extensive in the rural areas.

This forestry-based industrialisation contributed to the virtual simultaneity of the capitalist transformation both in industry and in agriculture. The agricultural transformation occurred relatively late, even among the prosperous

4 Carlsson 1968, pp. 252-67; Jörberg 1975, pp. 104-6; Åkerman 1975, p. 173; Blum 1978, pp. 438-9.

5 See Berend and Ránki 1974, pp. 30-9, 53, 67 (quotation), 122-9, 135-47; and Blum 1978, p. 437. 
peasants, only from the 1870 os on - later than the great agrarian reforms in Eastern Europe or, for example, the agricultural revolution in Scandinavia. ${ }^{6}$ Even as late as the 186os, Finland experienced a disastrous famine that resulted in a population decline of eight percent and demonstrated that traditional arable farming practices were very much a dead end. ${ }^{7}$ Thus late industrialisation and rapid population growth, as well as the linkage between the industrial and agricultural transformations, led in Finland to the simultaneous and related growth of the industrial and rural proletariat.

In other words, the situation in Finland was different not only from that in Sweden, where the rural proletariat had been absorbed as a result of industrial development, but also from that in Eastern Europe, where the industrial proletariat emerged only after land reforms had already given rise to a large landless proletariat.

Finnish conditions were aggravated, moreover, by the small scale of emigration. The rate of emigration, one indication of the breakup of traditional social arrangements, was lower than in Sweden. Those who left Finland for America between 1850 and 1910, for example, amounted to 7.7 percent of the 1910 population, whereas the corresponding figure for Sweden was 17.5 percent. $^{8}$ Furthermore, although emigration to America from East-Central Europe, as from Finland, began late, its relative importance was much greater.

Large-scale peasant ownership of forest land, together with the employment that forestry and the sawmills provided for the landless, accentuated the spread of capitalism to the Finnish countryside. The integration into the developed capitalist market system in the late nineteenth century was felt immediately by the rural population.

Many landowning peasants prospered, and the changeover from arable farming to stock-raising and dairy farming - the central feature of the Finnish agricultural revolution - became easier than would otherwise have been the case. As a well-known commentator described the development, 'Capitalism and the spirit of capitalism [began], consciously or unconsciously, to penetrate into peasant agriculture ... The landowning peasant had to produce more

6 Jörberg 1973, pp. 393-406; Winberg 1975, pp. 33-5; Soininen 1974, p. 412; Østerud 1978a, pp. 18994 .

7 Strömmer 1969, p. 22; Soininen 1974, pp. 402-15.

8 Rasila 1970, p. 19. 
for the market and to manage his farm like an enterprise; he had to begin to make calculations and to view economic activity from the point of profitability ... [In the process,] crofters, casual workers, and hired hands were increasingly exploited on the main farm'. ${ }^{9}$ At the same time, in 1865,1879 , and 1883 , restrictions on labour migration were removed, and hiring-out obligations were abolished. The everyday contacts between the freeholding peasant and his workers also appear to have changed. Contrary to earlier customs, the landowner and his family began to sleep and eat apart from the workers. ${ }^{10}$ Moreover, from the end of the century on, the children of freeholders who could not become farmers themselves increasingly left agriculture, mainly for various middle-class occupations. ${ }^{11}$

These observations suggest, first, a transition from peasant to farmer, or a change in which the landowning peasant entered the market more fully than before and explored alternative uses for the factors of production. Second, they suggest that this transformation also altered the relationship between the landowner and other agrarian groups, workers and crofters, as the landowner had increasingly to maximise his returns in the context of the market, regardless of the immediate consequences of his action. ${ }^{12}$

Both suggestions are supported by several facts. First, owners of large farms received enough forest income to make the changeover to dairy farming markedly easier. As Lennart Jörberg says in a comparative account, 'The introduction of more modern production methods, new equipment and better buildings all demanded a great deal of capital. If they had relied wholly on agricultural yield, Finnish farmers could hardly have come by this capital. Instead they acquired it to a great extent from the sale of forests and timber.13 Most important in this respect, apparently, was the role forest incomes played in relieving the indebtedness caused by the preceding crisis of arable cultivation. In 190o, for example, private citizens, essentially peasants, received go percent of the proceeds from the sale of standing timber. From 1860 to 1900 timber prices rose three or four times as fast as consumer prices. No wonder, then, that incomes in the countryside were more unevenly distributed during the closing decades of the last century than in the previous period. ${ }^{14}$

\footnotetext{
$9 \quad$ Forsman 1912, pp. 19, 26.

10 Myllyntaus 1981, p. 181; Soikkanen 1961, p. 8o.

11 According to Haapala's (1982, pp. 200-1) study of rural communities in the county of Häme.

12 See Wolf 1969, pp. xiv-xv, 286.

13 Jörberg 1973, pp. 400-1.

14 H. Kunnas 1973, pp. 87, 98; Hjerppe and Lefgren 1974, pp. 103-4. Cf. Hjerppe, Peltonen and Pihkala 1984, p. 43; M. Peltonen 1986, pp. 107-12.
} 
TABLE 3 Indicators of market penetration in the countryside, $1870-1910$

\begin{tabular}{|c|c|c|c|c|c|}
\hline & 1870 & $188 \circ$ & $189 \circ$ & 1900 & 1910 \\
\hline Total agrarian population, in thousands ${ }^{a}$ & 1,470 & 1,659 & 1,867 & 1,992 & 2,143 \\
\hline Area under cultivation, in thousands of hectares & - & 830 & 980 & $1,568^{b}$ & $1,878^{\mathrm{b}}$ \\
\hline $\begin{array}{l}\text { Marketed roundwood, in thousands of solid cubic } \\
\text { meters }\end{array}$ & 2,090 & 3,370 & 5,500 & 11,400 & 15,970 \\
\hline Milk produced, in millions of kilograms & $5^{20}$ & 701 & 963 & 1,326 & 1,541 \\
\hline Rural savings banks & 17 & 84 & 108 & 160 & 329 \\
\hline
\end{tabular}

a Includes the population engaged in agriculture and forestry.

b In 19o1. Then and in 1910 the definition of land under cultivation was broader than in the earlier period.

SOURCES: P. MANNINEN 1976, 81; SOININEN 1974, 130; RECENSEMENT AGRICOLE DE 1910

1916, 1; H. KUNNAS 1973, 110-111; VIITA 1965, 58-59; URBANS 1963, 449

Land prices also increased. One case study suggests that they increased in south-western Finland by over three and a half times in the period from $185^{\circ}$ until 19o6-10; ${ }^{15}$ a similar rise also occurred in central Finland: ${ }^{16}$ further indications of the widening gap between landowners and others. It seems reasonable to agree with the conclusion of Hannu Soikkanen that, owing to the central role of wood processing, the impact of industrialisation on life in the countryside was greater in Finland than in other countries at a comparable level of development. ${ }^{17}$

A number of other economic indicators attest to this change (see Table 3). Gentry estates were increasingly transferred to the peasants throughout the nineteenth century, most markedly in its latter half. Differences between manors and wealthy peasant farms nearly disappeared. The area under cultivation was greatly increased. Milk production quadrupled between 1870 and 1910 and soon became the largest source of income for farmers, particularly through butter exports. Cooperative dairies controlled by wealthy peasants spread rapidly at the turn of the century, as did the number of professional farmers' societies and savings banks that mainly served peasant landowners. ${ }^{18}$ At the same time, the farmers' tax burden fell significantly, for although their income increased, taxation remained at the previous level.

\footnotetext{
15 Kivialho 1927, pp. 118-21.

16 Markkanen 1977, pp. 6o-2.

17 Soikkanen 1981, pp. 441-2.

18 See, e.g., Soininen 1982, pp. 40-6; and Alapuro 198o, p. 5o.
} 
TABLE 4 Agrarian households in Finland by class, $1815^{-1901}$

\begin{tabular}{lcccccc}
\hline Class & $\mathbf{1 8 1 5}$ & $\mathbf{1 8 7 0}$ & $\mathbf{1 9 0 1}$ & $\begin{array}{c}\mathbf{1 8 1 5} \\
\text { (thousands) }\end{array}$ & $\begin{array}{c}\mathbf{1 8 7 0} \\
\text { (thousands) }\end{array}$ & $\begin{array}{c}\mathbf{1 9 0 1} \\
\text { (thousands) }\end{array}$ \\
\hline Landowners & $57 \%$ & $39 \%$ & $35 \%$ & 75 & 83 & 103 \\
Crofters $^{\mathrm{a}}$ & 28 & 32 & 17 & 38 & 68 & 49 \\
Agricultural workers & 15 & 29 & $48^{\mathrm{b}}$ & 19 & 60 & $139^{\mathrm{b}}$ \\
Total & $100 \%$ & $100 \%$ & $100 \%$ & 132 & 211 & 291 \\
\hline
\end{tabular}

a Includes other tenant farmers as well.

b In 1901 a number of scrapholders, who lived mainly by selling their labour power and who had previously been classified as crofters, were reclassified as agricultural workers. The relative increase in the number of households of agricultural workers and the relative decline in crofters' households is therefore somewhat exaggerated.

SOURCES: KILPI 1913, TABLES 33-36, 38, 54; GEBHARD 1913, 89, 92, 109

The political position of the freeholding peasants improved as well. Local government reforms instituted in 1865 guaranteed them power in local affairs. And at the national level they gained a great degree of influence once the Diet began to convene regularly after 1863 and the Peasant Estate for the first time gained equal status with the other estates.

These changes in themselves served to alter the relationship between the landowners and other agrarian groups. Moreover, not only was the wealth accruing from capitalist development distributed differentially among landowners and agricultural workers, but their relationship also changed directly.

The most important factor in this change was that the landowning population grew much more slowly than did the number of agricultural workers. During the last 30 years of the century, worker households grew in number from less than one-third to nearly one-half the total number of agrarian households, and the proportion of freeholding peasants decreased from 39 percent to 35 percent (see Table 4). This trend implies not only that new farms were not created on a large scale but also that few new croft leases were arranged. The significant increase in the amount of land under cultivation at the end of the nineteenth century, then, was not linked to the establishment of new crofts, as had previously been the case; rather, the landowner was now ready to cultivate more land personally and to use the farm for commercial dairy farming. Because the number of crofters did not increase, the growth rate of the agrarian proletariat accelerated, ${ }^{19}$ and it became largely a 'surplus' population. Accord-

19 According to a local study, only 20 percent of the crofters' children in the county of Häme 
ing to one estimate, in $1880,5^{\circ}-60$ percent of the then-current labour force would have been sufficient to maintain the prevailing level of agricultural production. ${ }^{20}$

A study made in the most densely populated and prosperous region of the country, the south-west, where the leasehold system was the most widespread and industrial growth the strongest, illustrates the development in the relationship between the landowners and the agrarian workers. Changes in agriculture and the rise in forest prices led to stricter leaseholds. Moreover, landowners divided part of their land into a number of small plots with high rents instead of creating traditional leasehold farms. Thus there emerged a new class of farm workers who lived by temporary work and lacked the relative independence of the crofters. As the population grew, the growth was channelled primarily into this new group, leading finally to an increase in emigration at the end of the century. $^{21}$

In other words, especially those groups that remained outside the traditional peasant community increased. To be a full member of the community, it was necessary to have a certain rough minimum amount of land. The process of modernisation considerably increased the number of those who held less than this minimum; ${ }^{22}$ indeed, this growing stratum had even less access to the land than did the crofters. As the landless population expanded without being effectively absorbed into industry, it remained in the countryside, producing a large number of agricultural workers. In 1910 there were 2.3 agricultural workers and 0.5 crofters and other tenant farmers for every landowner, and in the south-west the proportion was much higher, with 4.6 agricultural workers to every landowner. ${ }^{23}$

There is no doubt, then, that the commercialisation of agriculture considerably widened the gap between the landowners and the agrarian labourers. But although the latter became sharply differentiated from the freeholders, it would be erroneous to consider them badly hurt by the transformation. The rise of forestry not only benefited the owners of larger farms, but it also eased the conditions of the agrarian workers. Hence, "the "breakdown" of old economic forms' in the 186 os and thereafter did not cause them grave economic problems. In fact, their wages actually increased toward the end of the cen-

became crofters in the 1870 , whereas 42 percent became agrarian workers (Haapala 1982, p. $\left.5^{8}\right)$.

$20 \quad$ Kaukiainen 1981, p. 55 .

21 Gylling 1907, pp. 168-70.

22 Cf. Moore 1966, pp. 474-5.

23 Population de la Finlande au 31 décembre 1910 1915, 2:62, 66. 
tury owing both to the work available in logging and floating and to the rise in agricultural productivity. ${ }^{24}$ On the one hand, then, the forestry-based capitalist transformation made large groups of the landless a definite and increasingly distinct agrarian lower class, but on the other hand this change caused them no real distress. Both these aspects are significant for understanding the character of the agrarian workers' political mobilisation in the first decades of the twentieth century (see Chapter 6).

\section{The Link between Industrial and Agrarian Workers}

The nature of capitalist development influenced the make-up not only of the non-landowning agrarian population (both workers and crofters) but also of the industrial working class. Industrial expansion took place largely in rural areas, as evidenced by the fact that the industrial population grew more rapidly than the urban population in the late 1800 s. New plants such as sawmills, pulp mills, and paper factories spread throughout the countryside, and in 1910 nearly half the industrial workers lived there, with the sawmill industry alone employing one-quarter, and the wood industry as a whole one-third, of the total industrial labour force. The maximum sawing period per year is estimated to have been only about 19o days in 1880, 220 in 1900; thus, seasonal fluctuation was substantial. Moreover, as just stated, labour-intensive logging and floating provided significant employment for the landless. ${ }^{25}$

Internal migration increased toward the end of the nineteenth century. Set in motion partly by logging and floating jobs, people were gradually pulled toward industrial communities. Migration was facilitated by the fact that many industrial plants, particularly sawmills, pulp and paper factories, and iron works, employed a large number of unskilled workers. Also, many cities grew in the latter years of the nineteenth century as a result of the influx of the landless. In 1870 a narrow majority of the young workers in Tampere, Finland's first and leading large-scale industrial centre, had come from non-landowning rural families, with an additional 20 percent from the freeholding peasantry. Thereafter self-recruitment increased, but in 1910 the proportion of the children of crofters and the landless was still more than one-third. ${ }^{26}$ Likewise, at the turn

24 Heikkinen et al. 1983, pp. 24-36, 88 (quotation); Soininen 1981, pp. 97-111; Ahvenainen 1984, pp. 303-4.

25 Heikkinen and Hoffman 1982, p. 55; Peltonen 1982, p. 85; Hjerppe and Heikkinen 1978, p. 22; Hoffman 1981, p. 118.

26 Haapala 1982, pp. 56-6o, 197, 308. In 1910, fewer than 40 percent of the young workers 
of the century nearly two-thirds of the 100,ooo inhabitants of the capital, Helsinki, had been born elsewhere. Over half of those who moved to Helsinki toward the end of the century had previously been part of the landless rural proletariat. $^{27}$

All in all, owing to Finland's late industrialisation and the close linkage between the industrial and agricultural transformations, the industrial and agrarian proletariat developed simultaneously and were linked together. For the great majority of the proletariat - that is, the agrarian workers - the connection with the emerging industrial working class was fairly close, for several reasons. First, capitalist development changed the relationship of the growing landless population and the landowners. Through liberal reforms, which enabled the landless to move and sell their labour power, and industrialisation, which contributed directly to the commercialisation process in agriculture, the landless became an increasingly distinct class vis-à-vis the landed. Second, at the same time that the agrarian transformation occurred, an industrial working class emerged that had close connections with the agrarian proletariat. Indeed, the borderline between these two groups was rather hazy, thanks to the marked rural expansion of the sawmills and the wood-processing industry and to seasonal floating and logging. Finally, an overwhelming majority of the industrial workers had been recruited directly from the agrarian population. In the first decades of the twentieth century the Finnish industrial working class was rooted firmly in the countryside.

\section{$4 \quad$ Crofters}

The crofters occupied a position different from that of the agrarian workers. The former were small leaseholders who obtained their main livelihood from farming. Usually they worked a minimum of three hectares (1.2 acres), sometimes much more, and kept a couple of cows. Rent was paid mainly by working a certain number of days for the landowner and, to a lesser extent, by payments in kind or money. In the early 1800 s the position of the leaseholder was often rather similar to that of the freeholding peasant. The situation changed decisively only toward the end of the century.

The first political protests in late nineteenth-century Finland were by the crofters. Their collective actions against the landowners - mainly demonstra-

in Tampere were second-generation urban workers who were born there (Haapala 1982, p. 191).

Waris 1932, pp. 298, 300. 
tions and petitions - received much attention during the 1880 s, and by the turn of the century the so-called leasehold question had become a major political problem for the dominant groups. ${ }^{28}$

It may be argued that the leasehold question resulted from pressures caused by the capitalist development to a pre-capitalist tenancy system. Agreements concerning rents, rights of occupancy, and length of tenancy were usually oral and fairly unambiguous - customary and mutually understood - in the period when the landowner's connection with the market was limited. With the commercialisation of agriculture, however, the role of the croft in the landowner's household changed. Market requirements strained the relationship between the landowner and the leaseholder; consequently, the oral agreements were interpreted in conflicting ways and became a subject of controversy.

Toward the end of the century it became common for landowners to evict crofters and add the land that they had cleared and cultivated to the main farm, to reduce the crofters' forest rights, to increase rent, and to reduce the length of tenancies. Rents were augmented to the extent that the crofters' incomes grew very slowly, if at all. At the same time, as noted above, the wages of the agricultural labourers were going up discernibly. ${ }^{29}$ The number of crofts relative to freehold farms decreased significantly in the second half of the nineteenth century (see Table 4). Also, landowners increasingly alleged laziness on the part of the crofters, a reflection, in part, of the demands of market production. ${ }^{30}$ The crofts were losing their significance for the management of the main farm, as indicated by the increasing replacement of work rent by monetary payments after 190o. This practice served to weaken the productive link between the leasehold farm and the main farm. Although day labour remained the main form of rent, the spread of monetary payments shows that hired labour was becoming more advantageous than the crofters' day labour, at least on large farms. A 'free' labour force was widely and cheaply available. ${ }^{31}$

Late industrialisation seems to have aggravated the conflict between the freeholding peasants and the crofters, preventing not only the landless but also the crofters from moving elsewhere. The tenancy system did not fade away gradually and smoothly, as in Sweden. In Finland crofters were forced to remain where they were and to fight for their rights. In Sweden crofts increased in number into the 186os, after which they then began quickly to decline, dropping by 1900 to two-thirds of the 186os level. In Finland, in contrast, the number

\footnotetext{
28 See Rasila 1961.

29 Heikkinen et al. 1983, pp. 24-46, 95, 100-1.

$30 \quad$ Rasila 1970 , p. 17.

31 Ibid., pp. 34-5; Haatanen 1968, pp. 105, 172.
} 
of crofts was slightly greater in 1900 than in 186o, although their proportion had clearly declined. Monetary payments to landowners were also much more common in Sweden than in Finland. ${ }^{32}$

To conclude, like the agrarian workers, the crofters had grievances against the landowners. But in other respects the situations of the two groups were not similar. The crofters had access to the land, and the principal defence strategy open to them was to try to strengthen this control. Both similarities and differences in the two groups' positions were, naturally enough, to manifest themselves in their political reactions. But the somewhat varying structural positions only set certain minimum conditions for these reactions. The actual fusion or dissociation in the crofters' and the workers' organisation and mobilisation was to be powerfully determined by development of the political scene at the turn of the century and thereafter.

32 Rasila 1961, pp. 22, 36-9; Rasila 1970, p. 32; Haatanen 1968, p. 176. 